\title{
Effects of Different NaCl Doses on Morphological and Physiological Parameters in Mentha piperita L.
}

\author{
Ozlem Altuntas $^{1}$, Sebnem Kusvuran ${ }^{2}$ and Hayriye Yildiz Dasgan ${ }^{3}$ \\ 1. Department of Horticulture, Faculty of Agriculture, Inonu University, Malatya 44260, Turkey \\ 2. Department of Plant and Animal Production, Kizilirmak Vocational School, Karatekin University, Kizilirmak, Cankiri 18280, \\ Turkey \\ 3. Department of Horticulture, Faculty of Agriculture, Cukurova University, Balcali, Adana 01250, Turkey
}

\begin{abstract}
Salt stress is one of the most serious limiting factors for crop growth and production. This study was carried out to evaluate the effects of salt stress in four Mentha piperita L. varieties, in greenhouse conditions. The seedlings were irrigated with $1 / 2$ Hoagland nutrition solutions. Following $10 \mathrm{~d}$ of growth in the pots, the seedlings were subjected to salt stress with different concentrations of $\mathrm{NaCl}(0,50$ and $100 \mathrm{mM}$, respectively). Responses of the mint varieties to salt stress were evaluated using some plant growth and physiological parameters, such as plant height, root length, shoot and root fresh and dry weight, and ion concentrations in leaves, such as $\mathrm{Na}, \mathrm{K}, \mathrm{Ca}$ and $\mathrm{Cl}$. Salt stress caused reduction in physiological parameters. However, this reduction was significant at $100 \mathrm{mM} \mathrm{NaCl}$ compared to $50 \mathrm{mM} \mathrm{NaCl}$. These two concentrations of $\mathrm{NaCl}$ increased $\mathrm{Na}$ and $\mathrm{Cl}$ contents in leaves. However, $\mathrm{K}$ and Ca contents were decreased with salinity. The results showed that Mentha piperita cv. Sewiss and Granada were found more tolerant to salt stress than cv. Marokko and Citaro.
\end{abstract}

Key words: Growth, Mentha piperita L., mineral nutrition, salt stress, seedlings.

\section{Introduction}

Agricultural production in arid and semi-arid regions around the world is under the threat of multiple abiotic stresses, such as salinity. Salinity stress is one of the most serious abiotic stresses that cause reduction in plant growth, development and yield in many regions of the world. Plants employ many strategies in response to abiotic stresses that ultimately enhance the plant growth and productivity in stressful environments. These phenomena include change in morphological and developmental pattern (growth plasticity), as well as physiological and biochemical processes against several stresses [1]. The symptoms of salt damage in plants change according to species. Salinity is a factor that affects whole metabolism of a plant, as well as its morphology and anatomy. Salinity reduces the ability of plants to

Corresponding author: Ozlem Altuntas, Ph.D., research fields: vegetable growing (in open field and greenhouse), plant physiology and bio-fertilizers. absorb water, causing a reduction in growth rate and a suite of metabolic changes similar to those caused by water stress. The initial reduction in shoot growth is probably due to loss of cellular turgor pressure and hormonal signals generated by the roots [2]. Salinity, the common and comprehensive negative influence, can lead to apparent stunting of plant growth. From another point of view, slower growth is an available measure for plant survival under stress [3, 4]. Tang et al. [4] indicated that all of the physiological performances are the adaptive strategies for plants under salt stress. Some nutritional disturbances are expected under saline condition, resulting in high ratios of $\mathrm{Na} / \mathrm{Ca}$ and $\mathrm{Na} / \mathrm{K}$. In presence of $\mathrm{NaCl}$ excess in the medium, $\mathrm{Na}$ and $\mathrm{Cl}$ are accumulated in plant organs, and these saline ions can affect other mineral elements uptake through competitive interactions or by affecting the ion selectivity of membranes, which cause nutrient deficiencies in plants [5]. Salt-tolerant plants differ from salt-sensitive ones in having a low 
rate of $\mathrm{Na}^{+}$and $\mathrm{Cl}^{-}$transport to leaves and the ability to compartmentalize these ions in vacuoles to prevent their build-up in cytoplasm or cell walls and thus avoid salt toxicity [2].

Peppermint (Mentha piperita L.) is an important medicinal and aromatic plant grown in large areas in the world due to its economic importance. Its leaves have been used as a spice, while its essential oil is one of the most popular and widely used for food, pharmaceutical, cosmetic, personal care and cleaning industries for both its flavouring and fragrance [6]. $\mathrm{Li}$ et al. [7] showed that peppermint can not maintain normal growth and the biomass and yield of essential oil are severely decreased in the soils that contain more than $0.3 \% \mathrm{NaCl}(73.5 \mathrm{mM})$.

This study was carried out to determine the effect of different $\mathrm{NaCl}$ concentrations on some morphological and physiological parameters in different Mentha piperita $\mathrm{L}$. varieties.

\section{Materials and Methods}

Four different mint varieties (Mentha piperita cv. Sewiss, Granada, Marokko and Citaro), which were supplied from Germany, were used as plant materials. Plants were grown at Antalya Tarim Company's greenhouse. Seedlings were transferred to plastic pots containing $2 \mathrm{~L}$ mixture of peat: perlite of 1:1 ratio at Karaisali Vocational School's greenhouse, Cukurova University. Seedlings were irrigated with $1 / 2$ Hoagland nutrition solutions $\left(2.53 \mathrm{mM} \mathrm{KNO}_{3}\right.$, $0.75 \mathrm{mM} \mathrm{Ca}\left(\mathrm{NO}_{3}\right)_{2} \cdot 4 \mathrm{H}_{2} \mathrm{O}, 0.50 \mathrm{mM} \mathrm{NH}_{4} \mathrm{H}_{2} \mathrm{PO}_{4}, 0.50$ $\mathrm{mM} \mathrm{MgSO}_{4} \cdot 7 \mathrm{H}_{2} \mathrm{O}, 4.10 \mathrm{mM} \mathrm{FeSO} \cdot 7 \mathrm{H}_{2} \mathrm{O}, 2.03 \mathrm{mM}$ $\mathrm{Na}_{2}$-EDTA, $\quad 11.58 \quad \mathrm{mM} \quad \mathrm{H}_{3} \mathrm{BO}_{3}, \quad 2.28 \quad \mathrm{mM}$ $\mathrm{MnCl}_{2} \cdot 4 \mathrm{H}_{2} \mathrm{O}, 0.08 \mathrm{mM} \mathrm{CuSO} \cdot 5 \mathrm{H}_{2} \mathrm{O}, 0.15 \mathrm{mM}$ $\mathrm{H}_{2} \mathrm{MoO}_{4} \cdot \mathrm{H}_{2} \mathrm{O}, 0.40 \mathrm{mM} \mathrm{ZnSO} \cdot 7 \mathrm{H}_{2} \mathrm{O}$ ). Following 10 $\mathrm{d}$ of growth in the pots, seedlings were subjected to salt stress with 0,50 and $100 \mathrm{mM} \mathrm{NaCl}$, respectively. However, the control plants were irrigated with $1 / 2$ Hoagland nutrition solutions to end of the treatment. The applied amount of water in the study was calculated according to the ratio of "drained water/applied water", and this ratio was approximately $30 \%$. Since the study was conducted between from beginning of April and July, the plants were sprinkled every other day. The mint plants were subjected to salt stress for $97 \mathrm{~d}$. The control plants were grown under non-stress conditions for the same period of time. The experiment was designed as a completely randomized blocks with three replications (three plants per replication).

Responses of the mint varieties to salt stress were evaluated by some plant growth and physiological parameters, such as plant height, root length, shoot and root fresh and dry weight, and ion contents in leaves, such as $\mathrm{Na}, \mathrm{K}, \mathrm{Ca}$ and $\mathrm{Cl}$.

Plant nutritional elements analyses were done by the method of dry-ashing. The leaves were dried, grinded and then burned at $550{ }^{\circ} \mathrm{C}$. In the next step, they were solubilized in $3.3 \%(\mathrm{v} / \mathrm{v}) \mathrm{HCl}$ solution and the elements of $\mathrm{K}, \mathrm{Ca}$ and Na readings were done by the atomic absorption spectrophotometer [8, 9].

Obtained data were subjected to analysis of variance (ANOVA) using statistical analysis system, followed by Duncan's multiple range tests, and significant difference level was at $P<0.05$ by SPSS 16.0 software.

\section{Results and Discussion}

In the present study, the growth and ion accumulation of four mint varieties exposed to different salt levels which were imposed at early developmental stage of plants were investigated. Results showed that salt stress considerably reduced the growth of mint varieties in terms of shoot height, root length, shoot and root fresh and dry weight (Table 1). The highest shoot height and root length were obtained for the control group $(0 \mathrm{mM} \mathrm{NaCl})$. Due to salt stress, the highest decreases in these parameters, compared to the control, were observed in plants grown on $100 \mathrm{mM} \mathrm{NaCl}$ (16\%-60\% decrease). However, the decrease in shoot height and root length reached 36.88\% in Granada and 60.03\% in Citaro with 
Table 1 Effects of different concentrations of $\mathrm{NaCl}$ on morphological parameters in four mint varieties.

\begin{tabular}{|c|c|c|c|c|c|c|c|}
\hline Varieties & $\begin{array}{l}\mathrm{NaCl} \\
(\mathrm{mM})\end{array}$ & $\begin{array}{l}\text { Plant height } \\
(\mathrm{cm})\end{array}$ & $\begin{array}{l}\text { Root length } \\
(\mathrm{cm})\end{array}$ & $\begin{array}{l}\text { Root fresh } \\
\text { weight (g) }\end{array}$ & $\begin{array}{l}\text { Shoot fresh } \\
\text { weight (g) }\end{array}$ & $\begin{array}{l}\text { Root dry } \\
\text { weight (g) }\end{array}$ & $\begin{array}{l}\text { Shoot dry } \\
\text { weight (g) }\end{array}$ \\
\hline & 0 & $81.33^{\mathrm{a}}$ & $47.17^{\mathrm{a}}$ & $75.92^{\mathrm{a}}$ & $68.90^{\mathrm{a}}$ & $9.00^{\mathrm{a}}$ & $18.40^{\mathrm{a}}$ \\
\hline \multirow[t]{3}{*}{ Citaro } & 50 & $43.00^{\mathrm{b}}$ & $35.00^{\mathrm{b}}$ & $38.84^{\mathrm{b}}$ & $36.59^{\mathrm{b}}$ & $5.79^{\mathrm{b}}$ & $7.38^{\mathrm{b}}$ \\
\hline & 100 & $32.50^{c}$ & $26.67^{c}$ & $27.53^{c}$ & $22.58^{\mathrm{c}}$ & $4.59^{\mathrm{b}}$ & $5.99^{\mathrm{b}}$ \\
\hline & 0 & $40.67^{\mathrm{a}}$ & 38.33 & $49.05^{\mathrm{a}}$ & $61.04^{\mathrm{a}}$ & $9.42^{\mathrm{a}}$ & $16.47^{\mathrm{a}}$ \\
\hline \multirow[t]{3}{*}{ Granada } & 50 & $29.67^{\mathrm{b}}$ & 33.33 & $27.18^{\mathrm{b}}$ & $38.96^{\mathrm{ab}}$ & $3.39^{\mathrm{b}}$ & $9.37^{\mathrm{b}}$ \\
\hline & 100 & $25.67^{\mathrm{b}}$ & 32.00 & $23.39^{\mathrm{b}}$ & $28.10^{\mathrm{b}}$ & $2.62^{\mathrm{b}}$ & $7.60^{\mathrm{b}}$ \\
\hline & 0 & $42.53^{\mathrm{a}}$ & $40.50^{\mathrm{a}}$ & $73.98^{\mathrm{a}}$ & $54.03^{\mathrm{a}}$ & $16.36^{\mathrm{a}}$ & $14.25^{\mathrm{a}}$ \\
\hline \multirow[t]{3}{*}{ Marokko } & 50 & $26.50^{\mathrm{b}}$ & $36.67^{\mathrm{b}}$ & $38.37^{\mathrm{b}}$ & $22.83^{\mathrm{b}}$ & $5.09^{\mathrm{b}}$ & $8.06^{\mathrm{b}}$ \\
\hline & 100 & $21.67^{\mathrm{b}}$ & $29.33^{\mathrm{b}}$ & $30.16^{\mathrm{c}}$ & $14.31^{\mathrm{b}}$ & $3.71^{\mathrm{b}}$ & $6.34^{\mathrm{b}}$ \\
\hline & 0 & $46.33^{\mathrm{a}}$ & $46.50^{\mathrm{a}}$ & $66.28^{\mathrm{a}}$ & $55.89^{\mathrm{a}}$ & $13.54^{\mathrm{a}}$ & $13.25^{\mathrm{a}}$ \\
\hline \multirow[t]{2}{*}{ Sewiss } & 50 & $32.67^{\mathrm{b}}$ & $34.67^{\mathrm{b}}$ & $38.62^{\mathrm{b}}$ & $39.23^{\mathrm{b}}$ & $7.44^{\mathrm{b}}$ & $8.29^{b}$ \\
\hline & 100 & $28.40^{\mathrm{c}}$ & $28.33^{\mathrm{c}}$ & $29.72^{\mathrm{b}}$ & $23.94^{c}$ & $4.79^{b}$ & $6.32^{\mathrm{b}}$ \\
\hline
\end{tabular}

Different letters denote statistical difference by Duncan test $(P<0.05)$ among treatments.

$100 \mathrm{mM} \mathrm{NaCl}$ compared with the control. Both decreases were observed for plant height.

The results showed that different concentrations of $\mathrm{NaCl}$ had significant effects on the fresh and dry weights of shoots and roots. For all mint varieties, these parameters were the highest for the control. The most important decreases of fresh and dry weights in shoot, compared to the control, were observed in Marokko (55.51\% and 73.51\%) and Citaro varieties (67.45\% and 67.23\%) in $50 \mathrm{Mm}$ and $100 \mathrm{Mm} \mathrm{NaCl}$ treatment, respectively. However, Sewiss (57.17\% and $52.30 \%$ ) and Granada (53.96\% and 53.86\%) in shoot fresh and dry weight, respectively, showed the lowest reductions on $100 \mathrm{mM} \mathrm{NaCl}$. Root fresh and dry weight of mint varieties dramatically decreased depending on salt stress levels. The highest root fresh weight was determined in Citaro at the control group (75.92 g), while the lowest value was observed in Granada (23.39 g). The root fresh and dry weight for Granada and Citaro varieties decreased on $\mathrm{NaCl} 100$ $\mathrm{mM}$ by $49.0 \%$ to $72.18 \%$, compared to the control. On the other hand, these reductions were $59.23 \%$ and $77.32 \%$ in Marokko. Salinity, which is a common and comprehensive negative influence, can lead to apparent stunting of plant growth [4]. Since salt stress involves both osmotic and ionic stresses, growth suppression is directly related to the total concentrations of soluble salts and the osmotic potential of soil solution. The detrimental effect is observed at the whole plant level as the death of plants or a decrease in productivity [10]. Results indicated that a reduction in growth under saline conditions is a consequence of several physiological responses, including the modification of ionic balance, water status, mineral nutrition, stomatal behavior, photosynthetic efficiency, and carbon allocation and utilization. Maintenance of plant water status is a fundamental phenomenon for the maintenance of normal growth of plants under stressful environment [11]. In this study, plant growth was significantly decreased by salt, especially in sensitive varieties (Marokko and Citaro). Reduction of seedling height is a common phenomenon of many crop plants grown under saline conditions. The general effects of salinity on plant growth reflect in a reduction in plant growth with shorter stature and sometimes fewer leaves, and roots are also reduced in length and mass [12, 13]. As the salt concentrations are increased, shoot and root fresh and dry weights of the cultivars are decreased. In this study, of all salinity concentrations, growth was inhibited in the Marokko and Citaro cultivars with 100 $\mathrm{mM} \mathrm{NaCl}$. Plant and root fresh and dry weights were decreased with increasing salinity [14], and many other studies also reported this trait as the main 
indicator of salinity tolerance. Under salinity, leaf water potential and thus photosynthetic activity will decrease. The reduction in photosynthetic rate is usually due to low stomatal conductance, which also reduces the transpiration rate. Thus, plant development is decreased [15].

All of the factors mentioned have the negative effects on plant development at physiological and biochemical levels. In order to evaluate the tolerance of plants to salinity stress, growth or survival of the plant is determined, because it integrates the up or down regulation of many physiological mechanisms arising within the plant [10, 16-18].

The sodium contents in leaves of all the varieties increased with the solution salinity. In average, the increase of $\mathrm{Na}$ contents were $383 \%$ and $648 \%$ at 50 $\mathrm{mM}$ and $100 \mathrm{mM}$ doses, respectively, when compared to the control groups (Table 2). The sensitive varieties, such as Marokko and Citaro, had a 657\%-700\% increase in leaf $\mathrm{Na}$ concentration compared to the control plants, while the Sewiss and Granada had a $587 \%-648 \%$ increase in the leaves.

The association between osmotic and ionic effects (ionic toxicity, nutritional deficiency, etc.) has been reported by Da Silva et al. [19] as the main reason of the growth reduction under salt stress. After $97 \mathrm{~d}$ of salt stress in this study, Na contents dramatically increased with different salt levels, while $\mathrm{K}$ contents significantly decreased in mint plants (Table 2). The mean $\mathrm{K}$ concentration of four varieties in non-saline control conditions, $50 \mathrm{mM}$ and $100 \mathrm{mM}$ saline were $5.71 \%, 2.64 \%$ and $5.71 \%$, respectively. This reduction was greater in Marokko and Citaro than that in Granda and Sewiss. Accumulation of $\mathrm{K}$ in Marokko and Citaro were decreased by $45 \%-47 \%$, however, Granda and Sewiss were decreased by 37\%-40\%. K accumulation was high in organs, and vice versa, in which Na concentration was low. In presence of salinity, Granda and Sewiss had significantly higher K/Na ratios than Marokko and Citaro. Jiang et al. [20] showed that decreased $\mathrm{Na}$ accumulation in plants is also accompanied by a higher $\mathrm{K}$ accumulation in maize seedling. Also Da Silva et al. [19] indicated that high $\mathrm{Na}$ concentration can induce $\mathrm{K}$ deficiency, inhibiting the activity of enzymes that require $\mathrm{K}$. Thus, the interaction between relative $\mathrm{K}$ and $\mathrm{Na}$ concentrations has been considered a key factor in determining salt tolerance in plants.

Ca plays a vital role in many physiological processes, such as membrane structure, stomatal function, cell division and cell wall synthesis, which influence growth and responses to environmental stresses. Moreover, it plays a significant role in osmoregulation [10]. Plant Ca concentration of the mint varieties in control, $50 \mathrm{mM}$ and $100 \mathrm{mM}$ saline conditions, in average, were $1.59 \%, 1.36 \%$ and $0.83 \%$,

Table 2 Effects of different concentrations of $\mathrm{NaCl}$ on $\mathrm{K}, \mathrm{Ca}, \mathrm{Cl}$ and Na contents in mint varieties.

\begin{tabular}{llllll}
\hline Varieties & $\mathrm{NaCl}(\mathrm{mM})$ & $\mathrm{K}(\%)$ & $\mathrm{Ca}(\%)$ & $\mathrm{Cl}(\%)$ & $\mathrm{Na} \mathrm{( \% )}$ \\
\hline \multirow{3}{*}{ Citaro } & 0 & $5.79^{\mathrm{a}}$ & $2.41^{\mathrm{a}}$ & $0.30^{\mathrm{c}}$ & $0.41^{\mathrm{c}}$ \\
& 50 & $4.05^{\mathrm{b}}$ & $1.22^{\mathrm{b}}$ & $1.97^{\mathrm{b}}$ & $2.20^{\mathrm{cb}}$ \\
\hline \multirow{3}{*}{ Granada } & 100 & $3.19^{\mathrm{b}}$ & $1.03^{\mathrm{b}}$ & $4.06^{\mathrm{a}}$ & $3.28^{\mathrm{b}}$ \\
& 0 & $5.44^{\mathrm{a}}$ & 1.83 & $0.38^{\mathrm{c}}$ & $0.47^{\mathrm{c}}$ \\
& 50 & $3.98^{\mathrm{b}}$ & 1.40 & $2.00^{\mathrm{b}}$ & $2.14^{\mathrm{cb}}$ \\
\hline \multirow{3}{*}{ Marokko } & 100 & $3.40^{\mathrm{b}}$ & 1.11 & $4.70^{\mathrm{a}}$ & $3.52^{\mathrm{b}}$ \\
& 0 & $5.60^{\mathrm{a}}$ & $1.82^{\mathrm{a}}$ & $0.17^{\mathrm{b}}$ & $0.52^{\mathrm{b}}$ \\
\hline \multirow{3}{*}{ Sewiss } & 50 & $4.36^{\mathrm{b}}$ & $1.43^{\mathrm{ab}}$ & $2.27^{\mathrm{a}}$ & $2.64^{\mathrm{ab}}$ \\
& 100 & $3.00^{\mathrm{c}}$ & $0.99^{\mathrm{b}}$ & $3.73^{\mathrm{a}}$ & $3.94^{\mathrm{a}}$ \\
\hline
\end{tabular}

Different letters denote statistical difference by Duncan test $(P<0.05)$ among treatments. 
respectively. Salinity application caused a significant decrease in Ca concentration with increased salt levels in the mint plants (Table 2). Significant reductions of Ca content were observed when plants submitted to $100 \mathrm{mM} \mathrm{NaCl}$. This reduction was 58\% in Citaro. On the other hand, Ca accumulation in Granada (1.11\%) was higher than other varieties under $100 \mathrm{mM}$ application. The ameliorating effects of Ca play a key role in membrane integrity and control of selective ion uptake and transport. High Ca concentration can reduce the permeability of plasma membranes to $\mathrm{Na}$ [21]. The reduction of membrane permeability to $\mathrm{Na}$ and Ca reduces the accumulation of Na. Presence of high Na concentration in the growth medium disturbs the uptake and transport of $\mathrm{Ca}$, and thus the plants with the capability of taking up more Ca from medium have higher $\mathrm{Ca} / \mathrm{Na}$ ratios [22, 23]. Results in this study showed that Granda and Sewiss improved Ca and limited $\mathrm{Na}$ intake, so that having higher $\mathrm{Ca}$ accumulation compared to Marokko and Citaro.

The chloride content in leaves increased linearly up to levels of $100 \mathrm{mM} \mathrm{NaCl}$. The $\mathrm{Cl}$ content in the 100 $\mathrm{mM}$ was about 2- and 4-fold higher than that in control and $50 \mathrm{mM} \mathrm{NaCl}$ treatment. In Marokko and Citaro, $\mathrm{Cl}$ content increased 2,094\% and 1,253\% at salt levels of $100 \mathrm{mM} \mathrm{NaCl}$. In contrast, this reduction was nearly 1,136\% and 1,148\% in Granda and Sewiss, respectively, under the same condition (Table 2). Results indicated an increase in tissue $\mathrm{Na}$ and $\mathrm{Cl}$ when salinity increased. Da Silva et al. [19] reported that greater $\mathrm{Na}$ and $\mathrm{Cl}$ accumulation in roots than plant has been considered a physiological trait indicator of salt tolerance in plants. The foliar accumulation of $\mathrm{Na}$ and $\mathrm{Cl}$ could inhibit plants growth and development. Moreover, Munns and Tester [24] remarked the association between genetic differences in the rate of $\mathrm{Cl}$ accumulation in leaves and the plant's salinity tolerance.

\section{Conclusions}

Salt stress significantly affects the initial growth of mint plants grown in salt levels up to $50 \mathrm{mM} \mathrm{NaCl}$. The highest reduction was determinated in $100 \mathrm{mM}$ $\mathrm{NaCl}$ application. The decrease of plant growth parameters in Marokko and Citaro under salinity, especially at $100 \mathrm{mM} \mathrm{NaCl}$, could be related to sensitivity of these varieties. Besides, Granada and Sewiss limited $\mathrm{Na}$ ion accumulation, and the accumulation of $\mathrm{K}$ and $\mathrm{Ca}$ was related to increase of $\mathrm{Na}$ and may play a role as an osmotic regulation to maintain the $\mathrm{K} / \mathrm{Na}$ and $\mathrm{Ca} / \mathrm{Na}$ rate in the cells when exposed to salt stress. The mint plants were moderately tolerant to salinity, and salt stress decreases plant growth and development. However, Granada and Sewiss varieties are more tolerant than Marokko and Citaro.

\section{Acknowledgments}

The authors are grateful to Antalya Tarim Company and Karaisali Vocational School, Cukurova University for all kinds of support in achieving this study.

\section{References}

[1] Fahad, S., Hussain, S., Matloob, A., Khan, F. A., Khaliq, A., Saud, S., Hassan, S., Shan, D., Khan, F., Ullah, N., Faiq, M., Khan, M. R., Tareen, A. K., Khan, A., Ullah, A., Ullah, N., and Huang, J. L. 2015. "Phytohormones and Plant Responses to Salinity Stress: A Review.” Plant Growth Regulation 75 (2): 391-404.

[2] Aziz, E. E., Al-Amier, H., and Craker, L. E. 2008. "Influence of Salt Stress on Growth and Essential Oil Production in Peppermint, Pennyroyal and Apple Mint.” J. Herbs Spices Med. Plants 14 (1-2): 77-87.

[3] Zhu, J. K. 2001. "Plant Salt Tolerance.” Trends Plant Sci. 6 (2): 66-71.

[4] Tang, X., Mu, X., Shao, H., Wang, H., and Brestic, M. 2015. "Global Plant Responding Mechanisms to Salt Stress: Physiological and Molecular Levels and Implications in Biotechnology.” Crit. Rev. Biotechnol. 35 (4): 425-37.

[5] Kusvuran, S., Ellialtioglu, S., Yasar, F., and Abak, K. 2007. "Effects of Salt Stress on Ion Accumulation and Activity of Some Antioxidant Enzymes in Melon (Cucumis melo L.).” Int. J. Food Agric. Environ. 5 (2): 351-4.

[6] Çoban, Ö., and Baydar, N. G. 2016. "Brassinosteroid Effects on Some Physical and Biochemical Properties and 
Secondary Metabolite Accumulation in Peppermint (Mentha piperita L.) under Salt Stress.” Ind. Crop Prod. 86: 251-8.

[7] Li, Z., Yang, H., Wu, X., Guo, K., and Li, J. 2015. “Some Aspects of Salinity Responses in Peppermint (Mentha piperita L.) to $\mathrm{NaCl}$ Treatment.” Protoplasma 252 (3): 885-99.

[8] The PerkinElmer Inc.. 1976. Analytical Methods for Atomic Absorption Spectrophotometry. Norwalk, CN: Perkin Elmer Corporation.

[9] Jones, J. B. 1972. "Plant Tissue Analysis for Micronutrients.” In Micronutrients in Agriculture, edited by Mortvedt, J. J., Giordano, P. M., and Lindsay, W. L. Madison, Wisconsin: Soil Science Society of American, 319-46.

[10] Kusvuran, S. 2012. "Influence of Drought Stress on Growth, Ion Accumulation and Antioxidative Enzymes in Okra Genotypes.” Int. J. Agric. Biol. 14 (3): 401-6.

[11] Ali, Q., and Ashraf, M. 2011. "Induction of Drought Tolerance in Maize (Zea mays L.) due to Exogenous Application of Trehalose: Growth, Photosynthesis, Water Relations and Oxidative Defense Mechanism.” J. Agron. Crop Sci. 197 (4): 258-71.

[12] Shannon, M. C., and Grieve, C. M. 1999. "Tolerance of Vegetable Crops to Salinity.” Scientia Hort. 78: 5-38.

[13] Kusvuran, A., Nazli, R. I., and Kusvuran, S. 2014. "Determination of Salinity Effects on Seed Germination in Different Red Fescue (Festuca rubra L.) Varieties.” Tarım Bilimleri Araştırma Dergisi 7 (1): 22-7.

[14] Zabihi-e-Mahmoodabad, R., Jamaati-e-Somarin, S., Khayatnezhad, M., and Gholamin, R. 2011. "The Study of Effect Salinity Stress on Germination and Seedling Growth in Five Different Genotypes of Wheat.” $A d v$. Environ. Biol. 5 (1): 177-9.

[15] Razzaghi, F., Ahmadi, S. H., Adolf, V. I., Jesen, C. R., Jacobsen, S. E., and Andersen, M. N. 2011. "Water
Relations and Transpiration of Quinoa (Chenopodium quinoa Willd.) under Salinity and Soil Drying.” J. Agron. Crop Sci. 197 (5): 348-60.

[16] Ashraf, M. 2004. "Some Important Physiological Selection Criteria for Salt Tolerance in Plants.” Flora 199 (5): 361-76.

[17] Azooz, M. M., Ismail, A. M., and Elhamd, M. F. A. 2009. "Growth, Lipid Peroxidation and Antioxidant Enzyme Activities as a Selection Criterion for the Salt Tolerance of Three Maize Cultivars Grown under Salinity Stress.” Int. J. Agric. Biol. 11: 21-6.

[18] Hajlaoui, H., El Ayeb, N., Pierre Garrec, J., and Denden, M. 2010. "Differential Effects of Salt Stress on Osmotic Adjustment and Solutes Allocation on the Basis of Root and Leaf Tissue Senescence of Two Silage Maize (Zea mays L.) Varieties.” Indus. Crops Prod. 31: 122-30.

[19] Da Silva, E. C., Nogueira, R. J. M. C., De Araújo, F. P., De Melo, N. F., and De Azevedo Neto, A. D. 2008. "Physiological Responses to Salt Stress in Young Umbu Plants.” Environ. Exp. Bot. 63 (1): 147-57.

[20] Jiang, C. Q., Cui, Q. R., Feng, K., Xu, D. F., Li, C. F., and Zheng, Q. S. 2016. "Melatonin Improves Antioxidant Capacity and Ion Homeostasis and Enhances Salt Tolerance in Maize Seedlings.” Acta Physiol. Plant. 38: 82.

[21] Grattan, S. T., and Grieve, C. M. 1999. "Salinity-Mineral Relations in Horticultural Crops.” Sci. Hort. 78: 127-57.

[22] Al-Karaki, G. N. 2000. "Growth, Water Use Efficiency and Sodium and Potassium Acquisition by Tomato Cultivars Grown under Salt Stress.” J. Plant Nutr. 23 (1): 1-8.

[23] Dasgan, H. Y., Aktas, H., Abak, K., and Cakmak, I. 2002. "Determination of Screening Techniques to Salinity Tolerance in Tomatoes and Investigation of Genotype Responses.” Plant Sci. 163 (4): 695-703.

[24] Munns, R., and Tester, M. 2008. "Mechanisms of Salinity Tolerance.” Annu. Rev. Plant Biol. 59: 651-81. 